\title{
Anti-tumor necrosis factor (TNF) drugs for the treatment of psoriatic arthritis: an indirect comparison meta-analysis
}

This article was published in the following Dove Press journal:

Biologics:Targets and Therapy

30 November 2012

Number of times this article has been viewed

\author{
Kristian Thorlund' \\ Eric Druyts ${ }^{2}$ \\ J Antonio Aviña-Zubieta ${ }^{3,4}$ \\ Edward J Mills ${ }^{1,2}$ \\ 'Department of Clinical Epidemiology \\ and Biostatistics, McMaster \\ University, Hamilton, Ontario, \\ Canada; ${ }^{2}$ Faculty of Health Sciences, \\ University of Ottawa, Ottawa, \\ Ontario, Canada; ${ }^{3}$ Department \\ of Medicine, University of British \\ Columbia, Vancouver, British \\ Columbia, Canada; ${ }^{4}$ Division of \\ Rheumatology, Department of \\ Medicine, University of British \\ Columbia, Vancouver, British \\ Columbia, Canada
}

Correspondence: Edward J Mills

Faculty of Health Sciences, University of

Ottawa, 43 Templeton Street, Ottawa,

Canada KIN 6XI

Email edward.mills@uottawa.ca.
Objective: To evaluate the comparative effectiveness of available tumor necrosis factor- $\alpha$ inhibitors (anti-TNFs) for the management of psoriatic arthritis (PsA) in patients with an inadequate response to disease-modifying antirheumatic drugs (DMARDs).

Methods: We used an exhaustive search strategy covering randomized clinical trials, systematic reviews and health technology assessments (HTA) published on anti-TNFs for PsA. We performed indirect comparisons of the available anti-TNFs (adalimumab, etanercept, golimumab, and infliximab) measuring relative risks (RR) for the psoriatic arthritis response criteria (PsARC), mean differences (MDs) for improvements from baseline for the Health Assessment Questionnaire (HAQ) by PsARC responders and non-responders, and MD for the improvements from baseline for the psoriasis area and severity index (PASI). When the reporting of data on intervention group response rates and improvements were incomplete, we used straightforward conversions based on the available data.

Results: We retrieved data from 20 publications representing seven trials, as well as two HTAs. All anti-TNFs were significantly better than control, but the indirect comparison did not reveal any statistically significant difference between the anti-TNFs. For PsARC response, golimumab yielded the highest RR and etanercept the second highest; adalimumab and infliximab both yielded notably smaller RRs. For HAQ improvement, etanercept and infliximab yielded the largest MD among PsARC responders. For PsARC nonresponders, etanercept, infliximab, and golimumab yielded similar MDs, and adalimumab a notably lower MD. For PASI improvement, infliximab yielded the largest MD and golimumab the second largest, while etanercept yielded the smallest MD. In some instances, the estimated magnitudes of effect were notably different from the estimates of previous HTA indirect comparisons.

Conclusion: There is insufficient statistical evidence to demonstrate differences in effectiveness between available anti-TNFs for PsA. Effect estimates seem sensitive to the analytic approach, and this uncertainty should be taken into account in future economic evaluations.

Keywords: anti-tumour necrosis factor drugs, biologic DMARDs, indirect comparison metaanalysis, psoriatic arthritis, health assessment questionnaire, psoriatic arthritis response criteria, psoriasis area and severity index

\section{Introduction}

Psoriatic arthritis (PsA) is an inflammatory disease affecting joints and connective tissues. ${ }^{1}$ PsA affects up to $30 \%$ of individuals with psoriasis, a chronic skin condition affecting $1 \%-2 \%$ of the general population. ${ }^{1}$ It can be a destructive disabling joint disease, with the severity increasing over time. ${ }^{1}$ There are no cures for PsA and so the focus of treatment has been on controlling symptoms and preventing damage to joints. 
Patients are typically treated first with nonsteroidal antiinflammatory drugs (NSAIDS), that help to reduce pain and inflammation of the joints. ${ }^{2}$ In patients with more severe disease, disease-modifying antirheumatic drugs (DMARDs), such as methotrexate, are often a first course of treatment. ${ }^{2}$ More recently, therapies that inhibit the pro-inflammatory protein - tumor necrosis factor (TNF) - are increasingly being used in patients who have failed traditional DMARD therapy. ${ }^{2}$

Currently, four anti-TNFs are indicated for the treatment of PsA in combination with methotrexate (MTX). So far two comparative effectiveness assessments of available anti-TNFs for PsA have been conducted, both in connection with a health technology assessment (HTA). ${ }^{3,4}$ However, because of methodological shortcomings and limitations, the inferences from these analyses are weakened. The first HTA included adjusted indirect comparisons of only three of the four indicated anti-TNFs (adalimumab, infliximab, and etanercept). ${ }^{3}$ In addition, although this HTA provided summary tables of the trial outcomes at different time points (eg, 14 weeks and 24 weeks), it was not clear which time points were used for producing the pooled comparative effectiveness estimates. The second HTA attempted to model only a few outcomes that lend themselves well to an economic model (ie, PsA response criteria [PsARC], Health Assessment Questionnaire [HAQ] by PsARC responders and nonresponders, and Psoriasis Area and Severity Index [PASI] mean change as a continuous variable). ${ }^{4}$ However, the shortage in available data on these outcomes led the authors to conduct what was effectively a Bayesian imputation analysis. Given the scarcity of the data used, it is evident that the effectiveness estimates and any accompanying cost-effectiveness estimates will be sensitive to the imputation assumptions, and that the "noninformative" priors elicited in the model may carry a relatively high degree of information, and thus bias the estimates of effect. ${ }^{5,6}$

To address the shortcomings of previous indirect comparisons, and in particular the most recent HTA report, we performed an exhaustive literature search and data extraction of all trial publications, data available in published meta-analyses, and data available from HTAs. We used all available data on outcomes to calculate previously missing trial results, and thereby obviated the shortcomings of the Bayesian approach. We then re-ran the indirect comparison to obtain "improved" estimates of effect on the outcomes used to derive quality-adjusted life year (QALY) estimates in a recent National Institute for Health and Clinical Excellence (NICE) HTA. ${ }^{4}$

\section{Methods}

\section{Eligibility criteria}

We included randomized controlled trials (RCTs) examining the efficacy of anti-TNF biological agents (adalimumab, etanercept, golimumab, and infliximab) for the treatment of PsA. RCTs studying adult populations with active and progressive PsA with an inadequate response to previous DMARD therapy were eligible. We included RCTs of any treatment dose and duration of the above-specified anti-TNF biologics. We excluded trials conducted among PsA populations that had an adequate response to DMARD therapy, or were naïve to DMARD therapy. We also excluded trials conducted among PsA populations with prior experience with anti-TNF agents, including an inadequate response. Furthermore, trials that did not have a placebo control and that examined nonanti-TNF biological agents were excluded.

\section{Search strategy}

In consultation with a medical librarian, two investigators (ED, KT) independently conducted a systematic literature search for RCTs. The search terms included "psoriatic arthritis," "biologic," "anti-TNF," and the generic and brand names of each of the agents (eg, "adalimumab," "etanercept," "golimumab," "infliximab"). The following electronic databases (from inception to week 15 [April 9-15], 2012) were searched: MEDLINE, EMBASE, and Cochrane CENTRAL. Searches were limited to RCTs in humans, but not limited by language. Additionally, we searched for published HTAs and systematic reviews to further identify completed RCTs and/or obtain additional data on the published clinical trials. Lastly, some additional data were provided by Merck-Shire-Dome, UK. The exact search strategy is available from the authors upon request.

\section{Study selection}

Following the systematic literature searches, the same two investigators (ED, KT) obtained the full manuscripts of relevant trials, and independently assessed the relevance of each to determine whether or not it fit the eligibility criteria listed above. Any discrepancies between the two investigators were resolved by consulting a third investigator (EM) if necessary. Trials that did not meet the eligibility criteria were excluded and their reference listed with reasons for exclusion. Eligible trials underwent a quality assessment by one investigator (ED), using a modified Jadad scale. ${ }^{7}$

\section{Data abstraction}

Data were extracted by one investigator (ED) and independently checked by a second investigator (KT). Disagreements between 
the data extracted were resolved by consulting a third investigator (EM) if necessary. We abstracted data on anti-inflammatory response as derived from the PSARC. Response of psoriatic skin lesions, as determined by the PASI, was also abstracted. Finally, functional status, as determined by the HAQ score, was abstracted overall, and by PsARC response, where possible. Definitions of each for the outcomes are presented in the Supplementary materials (Table S1). The following trial characteristics were also abstracted: study design, number of subjects, trial duration, outcome measures used, treatment dose and duration, concomitant therapies, and participant characteristics.

\section{Data synthesis}

\section{Outcomes}

We considered the same three outcomes as a previous HTA: the PsARC response, the HAQ mean change from baseline for PSARC responders and nonresponders, and the PASI mean change from baseline. Our primary endpoint was the last observed time point in the trial, before allowed dose escalation or treatment cross-over. We chose this because patients with escalated dose and patients that have crossed over are no longer comparable to patients on a fixed dose treatment in terms of estimating efficacy.

\section{Dealing with incomplete data}

The PsARC response was reported completely across all trial publications, and thus did not require any transformations or imputations. The HAQ mean change by PsARC responders and non-responders were made available to us through the full version of a recently published HTA. ${ }^{4}$ However, the HAQ scores from the Mease $2000^{8}$ and Mease $2004^{9}$ studies had been combined in this HTA, and the available placebo HAQ response had been compiled across Mease 2000, Mease 2004, and the IMPACT trials. ${ }^{16-18}$ For this reason we made use of the overall HAQ baseline and mean change scores extracted from the trial publications to calculate the summary statistics which were not reported (note all missing data points were fully derived and no imputations were needed). Table S2 provides a detailed overview of necessary data conversions for the HAQ outcome.

For the PASI mean change only IMPACT and IMPACT 2 had complete data. For the remaining trials except for Mease 2004, baseline PASI and associated standard deviations (SDs) as well as PASI50, PASI70, and PASI90 were available. We assumed that the absolute percentage mean change approximately followed a normal distribution and approximated the mean and standard deviation from the PASI50, PASI70, and PASI90 data. We then used the approximated distribution with the available baseline distribution to produce PASI mean changes, using simulations.
For Mease 2004, where no baseline data was available, we imputed data by random sampling from the other trials. Appendix 2 provides a detailed overview of necessary data conversions and imputations for the PASI outcome.

\section{Statistical models}

We performed frequentist indirect comparison meta-analyses using random-effects models. ${ }^{13}$ We obtained comparative relative risks (RR) with 95\% confidence intervals for PsARC, and mean difference (MD) estimates with 95\% confidence intervals for HAQ (PsARC responders and nonresponders) and PASI. All analyses were performed using StatsDirect (StatsDirect Ltd, Altrincham, UK) and R v. 2.14 (The R Project for Statistical Computing; http://www.R-project.org/).

For PsARC we pooled the response rate in the placebo group from all trials, and used simulation to produce the expected response rate with each of the treatments using the indirect RR estimates and associated $(\log )$ standard error estimates. For HAQ and PASI we pooled the control group mean responses from baseline across trials, and used simulation to produce the expected mean response with each of the treatments using the indirect MD estimates and associated standard error estimates. Our primary analysis was of the outcomes observed at last time point (before allowed dose escalation or cross-over). However, since the last observed time points across trials were not consistent, we performed sensitivity analysis where possible. For PsARC we performed sensitivity analysis using similar "short-term" (ie, 12-16 weeks) outcomes, and, separately, "long-term" (ie, 24 weeks) outcomes where available. These analyses were not possible for the HAQ and PASI outcomes as we only had data on one time point.

\section{Results \\ Identified studies}

Nineteen studies, representing seven RCTs, met our inclusion criteria. ${ }^{14-27}$ Two of these RCTs used adalimumab, ${ }^{14-19}$ two used etanercept, ${ }^{8-27}$ two used infliximab, ${ }^{10-24}$ and one used golimumab. ${ }^{20}$ Table 1 presents the characteristics of each RCT, and Table S3 presents the demographic characteristics of the patients included in each RCT. Twenty-nine studies examined in detail were excluded; reasons for exclusion are presented in Table S4. A schematic of the study selection process is presented in Figure 1.

\section{Indirect comparisons}

For all treatments for all outcomes (except for adalimumab for HAQ nonresponders), there was a statistically significant difference in favor of the treatment (allowing for 5\% type I error). 
Table I Characteristics of the included trials

\begin{tabular}{|c|c|c|c|c|c|c|}
\hline Trial & Intervention & Setting & $\begin{array}{l}\text { Blinded } \\
\text { period }\end{array}$ & $\begin{array}{l}\text { No of patients } \\
\text { randomized }\end{array}$ & $\begin{array}{l}\text { Quality } \\
\text { score }\end{array}$ & $\begin{array}{l}\text { Outcomes } \\
\text { of interest }\end{array}$ \\
\hline Mease et $\left.\mathrm{a}\right|^{8}$ & $\begin{array}{l}\text { ETN } \\
\text { (25 mg twice weekly) }\end{array}$ & NS & 12 weeks & 60 & $5 / 5$ & $\begin{array}{l}\text { HAQ, } \\
\text { PASI, PsARC }\end{array}$ \\
\hline Mease et $\mathrm{al}^{25-27}$ & $\begin{array}{l}\text { ETN } \\
\text { (25 mg twice weekly) }\end{array}$ & I7 sites in USA & 24 weeks & 205 & $4 / 5$ & PASI, PsARC \\
\hline IMPACT $^{10-12}$ & $\begin{array}{l}\text { INF }(5 \mathrm{mg} / \mathrm{kg} \text { at weeks } 0 \text {, } \\
2,6,14)\end{array}$ & $\begin{array}{l}9 \text { sites in Europe, } \\
\text { Canada, USA }\end{array}$ & 16 weeks & 104 & $4 / 5$ & HAQ, PsARC \\
\hline IMPACT $2^{21-24}$ & $\begin{array}{l}\text { INF }(5 \mathrm{mg} / \mathrm{kg} \text { at weeks } 0 \text {, } \\
2,6,14,22)\end{array}$ & $\begin{array}{l}36 \text { sites in Europe, } \\
\text { Canada, USA }\end{array}$ & 16 weeks & 200 & $4 / 5$ & $\begin{array}{l}\text { HAQ, } \\
\text { PASI, PsARC }\end{array}$ \\
\hline ADEPT $14-18$ & $\begin{array}{l}\text { ADA ( } 40 \mathrm{mg} \text { every } \\
\text { other week) }\end{array}$ & $\begin{array}{l}50 \text { sites in Europe, } \\
\text { Australia, Canada, USA }\end{array}$ & 24 weeks & 313 & $3 / 5$ & $\begin{array}{l}\text { HAQ, } \\
\text { PASI, PsARC }\end{array}$ \\
\hline Genovese et al ${ }^{19}$ & $\begin{array}{l}\text { ADA ( } 40 \mathrm{mg} \text { every } \\
\text { other week) }\end{array}$ & 16 sites in Canada, USA & 24 weeks & 100 & $5 / 5$ & HAQ, PsARC \\
\hline GO-REVEAL ${ }^{20}$ & $\begin{array}{l}\text { GOL ( } 50 \mathrm{mg} \text { or } 100 \mathrm{mg} \\
\text { every fourth week) }\end{array}$ & $\begin{array}{l}52 \text { sites in Europe, } \\
\text { Canada, USA }\end{array}$ & 24 weeks & 405 & $5 / 5$ & $\begin{array}{l}\text { HAQ, } \\
\text { PASI, PsARC }\end{array}$ \\
\hline
\end{tabular}

Abbreviations: ADA, adalimumab; ADEPT, Adalimumab Effectiveness in Psoriatic Arthritis Trial; ETN, etanercept; GOL, golimumab; GO-REVEAL, Golimumab-Randomized Evaluation of Safety and Efficacy in Subjects with Psoriatic Arthritis Using a Human Anti-TNF Monoclonal Antibody; HAQ, Health Assessment Questionnaire; IMPACT, Infliximab Multinational Psoriatic Arthritis Controlled Trial; INF, inflizimab; NS, not stated; PASI, Psoriasis Area and Severity Index; PsARC, Psoriatic Arthritis Response Criteria.

Figure 2 presents the direct estimates for each of the anti-TNF treatments compared with placebo. For PsARC response, golimumab yielded the highest relative risk (RR 3.45, 95\% CI: $2.39,4.99)$ and etanercept the second highest (RR 3.19, 95\% CI: 2.31, 4.42). Adalimumab and infliximab both yielded notably smaller RRs. Sensitivity analysis using different time points did not reveal any difference in PsARC response RRs (results not shown, but available from the authors upon request). For HAQ improvement, etanercept and infliximab yielded the largest MD among PsARC responders (0.43 and 0.41 , respectively). For PsARC nonresponders,

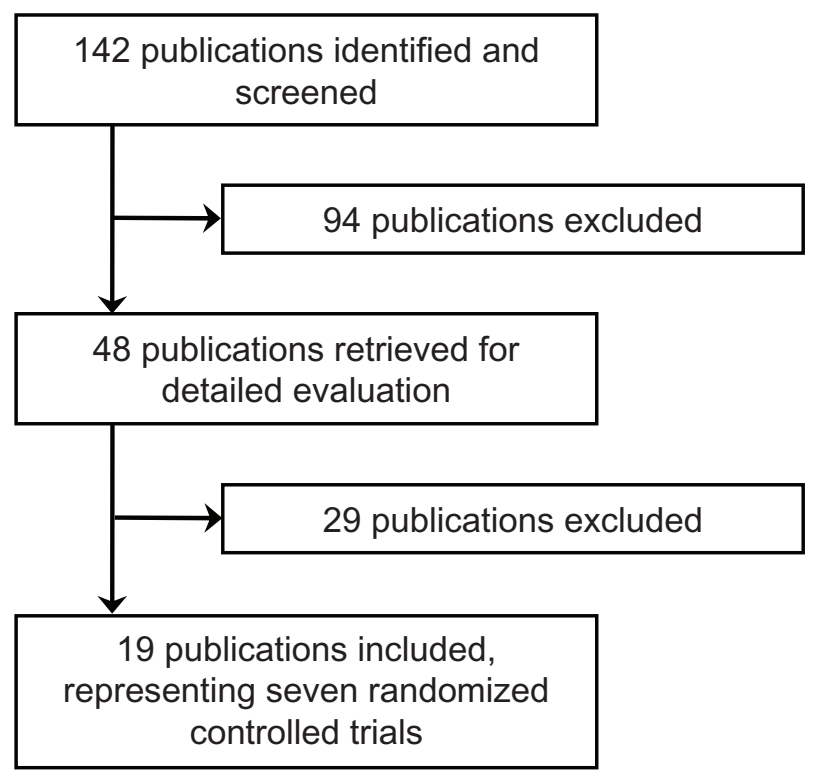

Figure I Schematic of the publication selection process. etanercept, infliximab, and golimumab yielded similar MDs, and adalimumab yielded a notably lower MD. For PASI improvement, infliximab yielded the largest MD and golimumab the second largest (6.44 and 4.90, respectively), while etanercept yielded the smallest MD (3.13).

Table 2 presents the indirect estimates between anti-TNF treatments. None of the four treatments were statistically significantly different for any of the outcomes.

Lastly, Table 3 presents the pooled control group responses and the expected intervention group responses using the indirect $\mathrm{RR}$ and MD estimates from the placebo comparison.

\section{Discussion}

Our indirect comparison of anti-TNF drugs for PsA was based on an extensive literature search and data extraction that allowed us to calculate trial results that were missing in previous indirect comparisons. No statistically significant difference was detected between the four anti-TNF drugs. When considering only the magnitude of estimated effect, the three anti-TNF drugs etanercept, infliximab, and golimumab seem to perform comparably better than adalimumab. When compared with each other, each of these three anti-TNFs performed better for one or two outcomes, but worse for one or two other outcomes (eg, golimumab yields the highest PsARC response, but the lowest average HAQ among PsARC nonresponders). In some instances, the treatment effect point estimates were also notably different from the estimates used to inform the recent NICE cost-effectiveness analysis. ${ }^{4}$ 


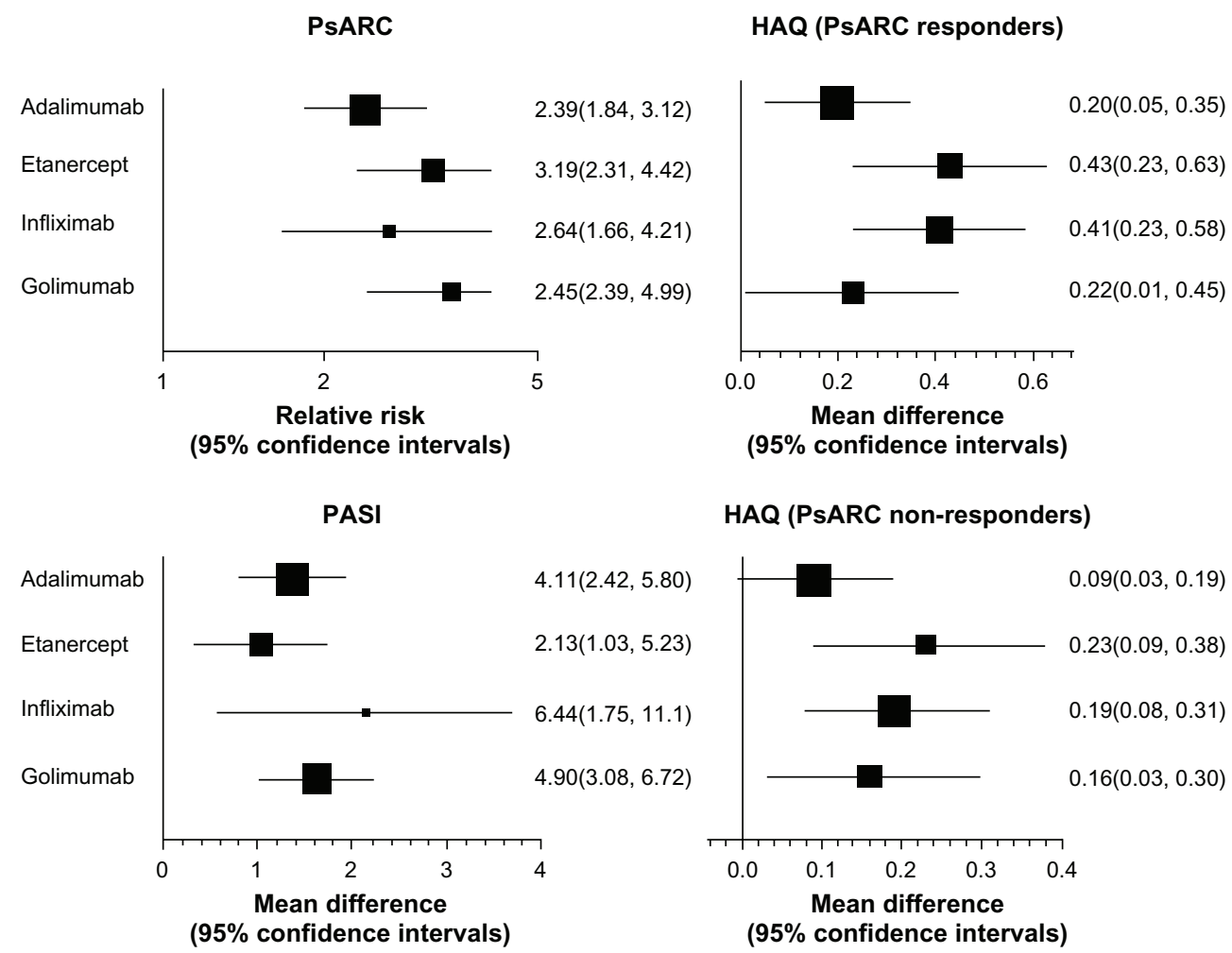

Figure 2 Forest plots of direct estimates for anti-TNFs versus placebo comparisons.

Abbreviations: anti-TNF, anti-tumor necrosis factor; HAQ, Health Assessment Questionnaire; PASI, Psoriasis Area and Severity Index; PsARC, Psoriatic Arthritis Response Criteria.

Our indirect comparison comes with a number of strengths and limitations. We performed an extensive search of all trial publications (several reports have been published for each trial ${ }^{14-29}$ ), previous systematic reviews, and HTAs. This allowed us to extract enough data to calculate the results of the outcomes of interest when missing. This also removed the necessity for Bayesian imputation models driven by priors. Despite the extensive data search and extraction, one cannot avoid the fact that the trial data are relatively sparse. Thus, calculations made for missing values and inferences regarding comparative effectiveness may be considerably impacted by random error. Some data may also have been suboptimal. For
HAQ improvement by PsARC responders, our etanercept data were a pooled analysis of the Mease 2000 and Mease 2004 trials. Although we were able to use trial reported HAQ scores to calculate and validate these results, some bias concerns exist with regards to Mease 2000, which we were not able to perform sensitivity analysis on. For PASI improvement, we only had continuous data available for about half of the trials. The conversion based on reported PASI50, PASI75, and PASI90 is only approximate, and may thus introduce some error. However, we do not believe this potential error is worse than the bias introduced by using falsely labeled "noninformative" priors in a Bayesian imputation model.

Table 2 Head-to-head indirect estimates of the anti-TNF drugs

\begin{tabular}{|c|c|c|c|c|}
\hline \multirow[t]{3}{*}{ Comparison } & \multirow{3}{*}{$\begin{array}{l}\text { PsARC } \\
\text { RR }(95 \% \mathrm{CI})\end{array}$} & \multirow{2}{*}{\multicolumn{2}{|c|}{$\begin{array}{l}\text { HAQ } \\
\text { MD }(95 \% \mathrm{Cl})\end{array}$}} & \multirow{3}{*}{$\begin{array}{l}\text { PASI } \\
\text { MD (95\% CI) }\end{array}$} \\
\hline & & & & \\
\hline & & Responders & Nonresponders & \\
\hline$A D A$ versus ETN & $0.75(0.49,1.24)$ & $-0.23(-0.51,0.05)$ & $-0.15(-0.33,0.03)$ & $0.98(-1.72,3.68)$ \\
\hline ADA versus INF & $0.91(0.53,1.32)$ & $-0.21(-0.48,0.06)$ & $-0.1 \mathrm{I}(-0.27,0.05)$ & $-2.33(-7.30,2.64)$ \\
\hline$A D A$ versus $G O L$ & $0.69(0.44,1.26)$ & $-0.03(-0.33,0.27)$ & $-0.08(-0.25,0.09)$ & $-0.79(-3.27,1.69)$ \\
\hline ETN versus INF & I.2I $(0.69,1.34)$ & $0.02(-0.26,0.30)$ & $0.04(-0.15,0.23)$ & $-3.31(-8.44,1.82)$ \\
\hline ETN versus GOL & $0.92(0.57,1.28)$ & $0.20(-0.10,0.50)$ & $0.07(-0.13,0.26)$ & $-1.77(-4.55,1.01)$ \\
\hline INF versus GOL & $0.76(0.42,1.35)$ & $0.18(-0.11,0.47)$ & $0.03(-0.15,0.21)$ & $1.54(-3.48,6.56)$ \\
\hline
\end{tabular}

Abbreviations: ADA, adalimumab; anti-TNF, anti-tumor necrosis factor; Cl, confidence interval; ETN, etanercept; GOL, golimumab; HAQ, Health Assessment Questionnaire; INF, infliximab; MD, mean difference; PASI, Psoriasis Area and Severity Index; PsARC, Psoriatic Arthritis Response Criteria; RR, relative risk. 
Table 3 Expected response rates and $95 \%$ confidence intervals for the three considered outcomes with the four anti-TNF drugs

\begin{tabular}{|c|c|c|c|c|c|}
\hline \multirow[t]{2}{*}{ Outcome } & \multirow{2}{*}{$\begin{array}{l}\text { Placebo } \\
\text { response }\end{array}$} & \multicolumn{4}{|c|}{ Anti-TNF treatment response } \\
\hline & & ADA & ETN & INF & GOL \\
\hline $\begin{array}{l}\text { PsARC response } \\
\text { (proportion) }\end{array}$ & $0.25(0.21,0.28)$ & $0.60(0.50,0.70)$ & $0.80(0.70,0.88)$ & $0.66(0.48,0.8 \mathrm{I})$ & $0.86(0.76,0.93$ \\
\hline $\begin{array}{l}\text { HAQ responders } \\
\text { (mean response) }\end{array}$ & $0.24(0.18,0.31)$ & $0.44(0.29,0.51)$ & $0.67(0.47,0.87)$ & $0.65(0.47,0.83)$ & $0.47(0.24,0.69$ \\
\hline $\begin{array}{l}\text { HAQ nonresponders } \\
\text { (mean response) }\end{array}$ & $0.01(-0.3,0.04)$ & $0.09(-0.02,0.18)$ & $0.24(0.10,0.39)$ & $0.19(0.09,0.32)$ & $0.17(0.04,0.31)$ \\
\hline $\begin{array}{l}\text { PASI } \\
\text { (mean response) }\end{array}$ & $0.68(0.31,1.04)$ & $4.79(3.10,6.48)$ & $3.81(1.71,5.91)$ & $7.12(2.43,11.78)$ & $5.58(3.76,7.40$ \\
\hline
\end{tabular}

Note: Confidence intervals are derived assuming a fixed placebo response.

Abbreviations: ADA, adalimumab; anti-TNF, anti-tumor necrosis factor; ETN, etanercept; GOL, golimumab; HAQ, Health Assessment Questionnaire; INF, infliximab; PASI, Psoriasis Area and Severity Index; PsARC, Psoriatic Arthritis Response Criteria.

This incongruence between magnitudes of effect estimates in our indirect comparison and previous indirect comparisons, strongly suggests sensitivity to analytic approaches that should not be overlooked in related economic evaluations. Patient utility can be derived by already established mathematical relationships between generic quality of life instruments such as the EQ-5D and the disease outcomes of interest (PsARC, HAQ, and PASI). While previous health economic assessments did perform a wide array of sensitivity analyses, these did not cover sensitivity to different analytic approach such as the 'imputation' used for our indirect comparison. Given that adalimumab, etanercept, golimumab, and infliximab are approved for use in PsA in many major settings, it is unlikely that we will see additional trials assessing the efficacy of these therapies, and so, economic evaluations will need to rely on the current available evidence. As such, it seems important to undertake a revision of current cost-effectiveness models to assess whether current drug indications are based on robust results, or need reconsideration.

\section{Conclusion}

Our indirect comparison did not demonstrate any significant difference between anti-TNF drugs for the treatment of PsA. In some instances, the magnitudes of effect in our indirect comparison differed from others. Since the analyzed outcomes play an important role informing quality adjusted life years (QALYs, and thus cost per QALY) in cost-effectiveness analyses, it seems reasonable to insist that the cost-effectiveness analyses on which the current drug indications are based be revised to check the robustness of their findings.

\section{Acknowledgments}

This study was sponsored by Merck, Sharp, \& Dohme, UK.

\section{Author contributions}

KT and EM conceived the design of the study. KT drafted the first manuscript. KT and ED extracted the data. KT performed the statistical analyses. All authors contributed to the interpretation of the findings and to the writing of the final version of the manuscript.

\section{Disclosure}

Kristian Thorlund and Edward Mills have consulted either Merck and Co, Inc, Pfizer Ltd, Nycomed, Takeda, Novartis or GlaxoSmithkline on multiple treatment comparison and systematic review issues. Kristian Thorlund and Edward Mills have received grant funding from the Canadian Institutes of Health Research (CIHR) Drug Safety and Effectiveness Network to develop methods and educational materials on MTCs. Edward Mills receives salary support from the Canadian Institutes of Health Research through a Canada Research Chair. Kristian Thorlund receives salary support from the CIHR Drug Safety and Effectiveness Network. The above authors report no other conflicts of interest in this work. Eric Druyts and Antonio Avina-Zubieta report no conflicts of interest in this work.

\section{References}

1. Gladman DD, Antoni C, Mease P, Clegg DO, Nash P. Psoriatic arthritis: epidemiology, clinical features, course, and outcome. Ann Rheum Dis. 2005;64 Suppl 2:ii14-ii17.

2. Ritchlin CT, Kavanaugh A, Gladman DD, et al. Treatment recommendations for psoriatic arthritis. Ann Rheum Dis. 2009;68(9): 1387-1394.

3. Rodgers M, Epstein D, Bojke L, et al. Etanercept, infliximab, and adalimumab for the treatment of psoriatic arthritis: a systematic review and economic evaluation. Health Technol Assess. 2011;15(10):i-xxi, 1-329.

4. Yang H, Craig D, Epstein D, et al. Golimumab for the treatment of psoriatic arthritis: a NICE single technology appraisal. Pharmecoeconomics. 2012;30(4):257-270.

5. Gelman A. Prior distributions for variance parameters in hiearchical models. Bayesian Anal. 2006;1(3):515-533. 
6. Lambert PC, Sutton AJ, Burton PR, Abrams KR, Jones DR. How vague is vague? A simulation study of the impact of the use of vague prior distributions in MCMC using WinBUGS. Stat Med. 2005;24(15): 2401-2428.

7. Jadad AR, Moore RA, Carroll D, et al. Assessing the quality of reports of randomized clinical trials: is blinding necessary? Control Clin Trials. 1996;17(1):1-12.

8. Mease PJ, Goffe BS, Metz J, VanderStoep A, Finck B, Burge DJ. Etanercept in the treatment of psoriatic arthritis and psoriasis: a randomised trial. Lancet. 2000;356(9227):385-390.

9. Mease PJ, Kivitz AJ, Burch FX, et al. Etanercept treatment of psoriatic arthritis: safety, efficacy, and effect on disease progression. Arthritis Rheum. 2004;50(7):2264-2272.

10. Antoni CE, Kavanaugh A, Kirkham B, et al. Sustained benefits of infliximab therapy for dermatologic and articular manifestations of psoriatic arthritis: results from the infliximab multinational psoriatic arthritis controlled trial (IMPACT). Arthritis Rheum. 2005;52(4): 1227-1236.

11. Antoni CE, Kavanaugh A, van der Heijde D, et al. Two-year efficacy and safety of infliximab treatment in patients with active psoriatic arthritis: findings of the Infliximab Multinational Psoriatic Arthritis Controlled Trial (IMPACT). J Rheumatol. 2008;35(5):869-876.

12. Kavanaugh A, Antoni CE, Gladman D, et al. The Infliximab Multinational Psoriatic Arthritis Controlled Trial (IMPACT): results of radiographic analyses after 1 year. Ann Rheum Dis. 2006;65(8): 1038-1043.

13. Bucher HC, Guyatt GH, Griffith LE, Walter SD. The results of direct and indirect treatment comparisons in meta-analysis of randomized controlled trials. J Clin Epidemiol. 1997;50(6):683-691.

14. Gladman DD, Mease PJ, Choy EH, Ritchlin CT, Perdok RJ, Sasso EH. Risk factors for radiographic progression in psoriatic arthritis: subanalysis of the randomized controlled trial ADEPT. Arthritis Res Ther. 2010;12(3):R113.

15. Gladman DD, Mease PJ, Cifaldi MA, Perdok RJ, Sasso E, Medich J. Adalimumab improves joint-related and skin-related functional impairment in patients with psoriatic arthritis: patient-reported outcomes of the Adalimumab Effectiveness in Psoriatic Arthritis Trial. Ann Rheum Dis. 2007;66(2):163-168.

16. Gladman DD, Mease PJ, Ritchlin CT, et al. Adalimumab for longterm treatment of psoriatic arthritis: forty-eight week data from the adalimumab effectiveness in psoriatic arthritis trial. Arthritis Rheum. 2007;56(2):476-488.

17. Mease PJ, Gladman DD, Ritchlin CT, et al. Adalimumab for the treatment of patients with moderately to severely active psoriatic arthritis: results of a double-blind, randomized, placebo-controlled trial. Arthritis Rheum. 2005;52(10):3279-3289.

18. Mease PJ, Ory P, Sharp JT, et al. Adalimumab for long-term treatment of psoriatic arthritis: 2-year data from the Adalimumab Effectiveness in Psoriatic Arthritis Trial (ADEPT). Ann Rheum Dis. 2009;68(5):702-709.

19. Genovese MC, Mease PJ, Thomson GT, et al. Safety and efficacy of adalimumab in treatment of patients with psoriatic arthritis who had failed disease modifying antirheumatic drug therapy. J Rheumatol. 2007;34(5):1040-1050.

20. Kavanaugh A, McInnes I, Mease P, et al. Golimumab, a new human tumor necrosis factor alpha antibody, administered every four weeks as a subcutaneous injection in psoriatic arthritis: Twenty-four-week efficacy and safety results of a randomized, placebo-controlled study. Arthritis Rheum. 2009;60(4):976-986.

21. Antoni C, Krueger GG, de Vlam K, et al. Infliximab improves signs and symptoms of psoriatic arthritis: results of the IMPACT 2 trial. Ann Rheum Dis. 2005;64(8):1150-1157.

22. Kavanaugh A, Antoni C, Krueger GG, et al. Infliximab improves health related quality of life and physical function in patients with psoriatic arthritis. Ann Rheum Dis. 2006;65(4):471-477.

23. Kavanaugh A, Antoni C, Mease P, et al. Effect of infliximab therapy on employment, time lost from work, and productivity in patients with psoriatic arthritis. J Rheumatol. 2006;33(11):2254-2259.
24. van der Heijde D, Kavanaugh A, Gladman DD, et al. Infliximab inhibits progression of radiographic damage in patients with active psoriatic arthritis through one year of treatment: Results from the induction and maintenance psoriatic arthritis clinical trial 2. Arthritis Rheum. 2007;56(8):2698-2707.

25. Mease PJ, KivitzAJ, Burch FX, et al. Continued inhibition of radiographic progression in patients with psoriatic arthritis following 2 years of treatment with etanercept. J Rheumatol. 2006;33(4):712-721.

26. Mease PJ, Woolley JM, Bitman B, Wang BC, Globe DR, Singh A. Minimally important difference of Health Assessment Questionnaire in psoriatic arthritis: relating thresholds of improvement in functional ability to patient-rated importance and satisfaction. J Rheumatol. 2011; 38(11):2461-2465.

27. Mease PJ, Woolley JM, Singh A, Tsuji W, Dunn M, Chiou CF. Patientreported outcomes in a randomized trial of etanercept in psoriatic arthritis. J Rheumatol. 2010;37(6):1221-1227.

28. Baranauskaite A, Raffayová H, Kungurov NV, et al; for RESPOND investigators. Infliximab plus methotrexate is superior to methotrexate alone in the treatment of psoriatic arthritis in methotrexatenaive patients: the RESPOND study. Ann Rheum Dis. 2012;71(4): 541-548.

29. Kimball AB, Bensimon AG, Guerin A, et al. Efficacy and safety of adalimumab among patients with moderate to severe psoriasis with co-morbidities: Subanalysis of results from a randomized, double-blind, placebo-controlled, phase III trial. Am J Clin Dermatol. 2011;12(1): 51-62.

30. Mease P, Genovese MC, Gladstein G, et al. Abatacept in the treatment of patients with psoriatic arthritis: results of a six-month, multicenter, randomized, double-blind, placebo-controlled, phase II trial. Arthritis Rheum. 2011;63(4):939-948.

31. Prinz JC, Fitzgerald O, Boggs RI, et al. Combination of skin, joint and quality of life outcomes with etanercept in psoriasis and psoriatic arthritis in the PRESTA trial. J Eur Acad Dermatol Venereol. 2011;25(5): 559-564.

32. Asahina A, Nakagawa H, Etoh T, Ohtsuki M; for Adalimumab M04688 Study Group. Adalimumab in Japanese patients with moderate to severe chronic plaque psoriasis: efficacy and safety results from a Phase II/III randomized controlled study. J Dermatol. 2010;37(4): 299-310.

33. Atteno M, Peluso R, Costa L, et al. Comparison of effectiveness and safety of infliximab, etanercept, and adalimumab in psoriatic arthritis patients who experienced an inadequate response to previous disease-modifying antirheumatic drugs. Clin Rheumatol. 2010;29(4): 399-403.

34. Mease PJ, Signorovitch J, Yu AP, et al. Impact of adalimumab on symptoms of psoriatic arthritis in patients with moderate to severe psoriasis: a pooled analysis of randomized clinical trials. Dermatology. 2010;220(1):1-7.

35. Sterry W, Ortonne JP, Kirkham B, et al. Comparison of two etanercept regimens for treatment of psoriasis and psoriatic arthritis: PRESTA randomised double blind multicentre trial. BMJ. 2010;340:c147.

36. Torii H, Nakagawa H; for Japanese Infliximab Study investigators. Infliximab monotherapy in Japanese patients with moderate-to-severe plaque psoriasis and psoriatic arthritis. A randomized, double-blind, placebo-controlled multicenter trial. J Dermatol Sci. 2010;59(1): 40-49.

37. van Kuijk AW, Gerlag DM, Vos K, et al. A prospective, randomised, placebo-controlled study to identify biomarkers associated with active treatment in psoriatic arthritis: effects of adalimumab treatment on synovial tissue. Ann Rheum Dis. 2009;68(8):1303-1309.

38. Bongiorno MR, Pistone G, Doukaki S, Aricò M. Adalimumab for treatment of moderate to severe psoriasis and psoriatic arthritis. Dermatol Ther. 2008;21 Suppl 2:S15-S20.

39. Brodszky V, Pentek M, Gulacsi L. Efficacy of adalimumab, etanercept, and infliximab in psoriatic arthritis based on ACR50 response after 24 weeks of treatment. Scand J Rheumatol. 2008; 37(5):399-400 
40. Feldman SR, Gottlieb AB, Bala M, et al. Infliximab improves healthrelated quality of life in the presence of comorbidities among patients with moderate-to-severe psoriasis. Br J Dermatol. 2008;159(3):704-710.

41. Kristensen LE, Gülfe A, Saxne T, Geborek P. Efficacy and tolerability of anti-tumour necrosis factor therapy in psoriatic arthritis patients: results from the South Swedish Arthritis Treatment Group register. Ann Rheum Dis. 2008;67(3):364-369.

42. Ravindran V, Scott DL, Choy EH. A systematic review and metaanalysis of efficacy and toxicity of disease modifying anti-rheumatic drugs and biological agents for psoriatic arthritis. Ann Rheum Dis. 2008;67(6):855-859.

43. Revicki D, Willian MK, Saurat JH, et al. Impact of adalimumab treatment on health-related quality of life and other patient-reported outcomes: results from a 16-week randomized controlled trial in patients with moderate to severe plaque psoriasis. Br J Dermatol. 2008;158(3): 549-557.

44. Saad AA, Symmons DP, Noyce PR, Ashcroft DM. Risks and benefits of tumor necrosis factor-alpha inhibitors in the management of psoriatic arthritis: systematic review and metaanalysis of randomized controlled trials. J Rheumatol. 2008;35(5):883-890.

45. Spadaro A, Ceccarelli F, Scrivo R, Valesini G. Life-table analysis of etanercept with or without methotrexate in patients with psoriatic arthritis. Ann Rheum Dis. 2008;67(11):1650-1651.

46. Strober B, Teller C, Yamauchi P, et al. Effects of etanercept on C-reactive protein levels in psoriasis and psoriatic arthritis. Br J Dermatol. 2008;159(2):322-330.

47. Frankel EH, Strober BE, Crowley JJ, et al. Etanercept improves psoriatic arthritis patient-reported outcomes: results from EDUCATE. Cutis. 2007;79(4):322-326.
48. Kimball AB, Jackson JM, Sobell JM, et al. Reductions in healthcare resource utilization in psoriatic arthritis patients receiving etanercept therapy: results from the educate trial. J Drugs Dermatol. 2007;6(3): 299-306.

49. Romero-Maté A, García-Donoso C, Córdoba-Guijarro S. Efficacy and safety of etanercept in psoriasis/psoriatic arthritis: an updated review. Am J Clin Dermatol. 2007;8(3):143-155.

50. Vander Cruyssen B, De Keyser F, Kruithof E, Mielants H, Van den Bosch F. Comparison of different outcome measures for psoriatic arthritis in patients treated with infliximab or placebo. Ann Rheum Dis. 2007;66(1):138-140.

51. Fransen J, Antoni C, Mease PJ, et al. Performance of response criteria for assessing peripheral arthritis in patients with psoriatic arthritis: analysis of data from randomised controlled trials of two tumour necrosis factor inhibitors. Ann Rheum Dis. 2006;65(10):1373-1378.

52. Gottlieb AB, Kircik L, Eisen D, et al. Use of etanercept for psoriatic arthritis in the dermatology clinic: the Experience Diagnosing, Understanding Care, and Treatment with Etanercept (EDUCATE) study. J Dermatolog Treat. 2006;17(6):343-352.

53. Ritchlin C. Efficacy and safety of infliximab for the treatment of psoriatic arthritis. Nat Clin Pract Rheumatol. 2006;2(6):300-301.

54. Kvien TK, Heiberg, Lie E, et al. A Norwegian DMARD register: prescriptions of DMARDs and biological agents to patients with inflammatory rheumatic diseases. Clin Exp Rheumatol. 2005; 23(5 Suppl 39):S188-S194.

55. Rinaldi F, Provenzano G, Termini A, Spinello M, La Seta F. Long term infliximab treatment for severe psoriatic arthritis: evidence of sustained clinical and radiographic response. Ann Rheum Dis. 2005;64(9): 1375-1376. 


\section{Supplementary materials}

Table SI Outcomes included in the analysis

Outcome

Definition

PsARC is defined as an improvement in at least two of the following four measures: patient selfassessment, physician assessment, joint pain/tenderness score, and joint swelling score. One of the two measures must be joint pain/tenderness score or joint swelling score. No worsening can occur in any of the four measures.

Psoriasis area and severity index (PASI)

PASI combines the assessment of the severity of lesions and the area affect into a score that spans from 0 (no disease) to 72 (maximal disease). At least $3 \%$ of the body surface area has to be affected by the psoriasis in order for the PASI measure to be used.

Health assessment questionnaire (HAQ) The HAQ focuses on two dimensions of health status: physical disability and pain, generating a score of 0 (least disability) to 3 (most severe disability).

Table S2 Imputations solutions and assumptions employed to construct PASI mean changes

\begin{tabular}{|c|c|c|}
\hline Trial & Data format & Imputation solutions and employed assumptions \\
\hline Mease et $\mathrm{al}^{13}$ & $\begin{array}{l}\text { Baseline median and range (assumed range }=2 \times 3 \mathrm{SEs} \text { ) } \\
\text { Percentage change from baseline }\end{array}$ & $\begin{array}{l}\text { Assume similar percentage change SD as Mease } 2004 \\
\text { Assume mean percentage change is normally distributed } \\
\text { Simulate PASI mean change scores from available baseline } \\
\text { and \% change data }\end{array}$ \\
\hline Mease et $\mathrm{al}^{25-27}$ & $\begin{array}{l}\text { Baseline not reported } \\
\text { Percentage change (SE) }\end{array}$ & $\begin{array}{l}\text { Assume similar baseline score as Mease } 2000 \\
\text { Assume mean percentage change is normally distributed } \\
\text { Simulate PASI mean change scores from assumed baseline } \\
\text { and available \% change data }\end{array}$ \\
\hline IMPACT $^{10-12}$ & $\begin{array}{l}\text { PASI }(\mathrm{BSA}>3 \%) \text { reported by PsARC responders } \\
\text { and nonresponders }\end{array}$ & $\begin{array}{l}\text { Take weighted average of PSARC responders and non- } \\
\text { responders }\end{array}$ \\
\hline IMPACT $2^{21-24}$ & $\begin{array}{l}\text { PASI }(\mathrm{BSA}>3 \%) \text { reported by PsARC responders } \\
\text { and nonresponders }\end{array}$ & Same as IMPACT \\
\hline ADEPT $^{14-18}$ & $\begin{array}{l}\text { Baseline PASI mean and SE } \\
\text { Percentage achieving } 50 \%, 75 \% \text {, and } 90 \% \\
\text { PASI improvement }\end{array}$ & $\begin{array}{l}\text { Assume percentage change is normally distributed } \\
\text { Approximate normal distribution mean and SE using available } \\
\text { percentiles (PASI50, PASI75, and PASI90 transformed) } \\
\text { Simulate PASI mean change scores from assumed baseline } \\
\text { and available \% change data }\end{array}$ \\
\hline GO-REVEAL 20 & $\begin{array}{l}\text { PASI }(B S A>3 \%) \text { reported by PsARC responders } \\
\text { and non-responders }\end{array}$ & Same as IMPACT \\
\hline
\end{tabular}

Abbreviations: ADEPT, Adalimumab Effectiveness in Psoriatic Arthritis Trial; BSA, body surface area; GO-REVEAL, Golimumab-Randomized Evaluation of Safety and Efficacy in Subjects with Psoriatic Arthritis Using a Human Anti-TNF Monoclonal Antibody; IMPACT, Infliximab Multinational Psoriatic Arthritis Controlled Trial; PASI, Psoriasis Area and Severity Index; PsARC, Psoriatic Arthritis Response Criteria; SD, standard deviation; SE, standard error. 


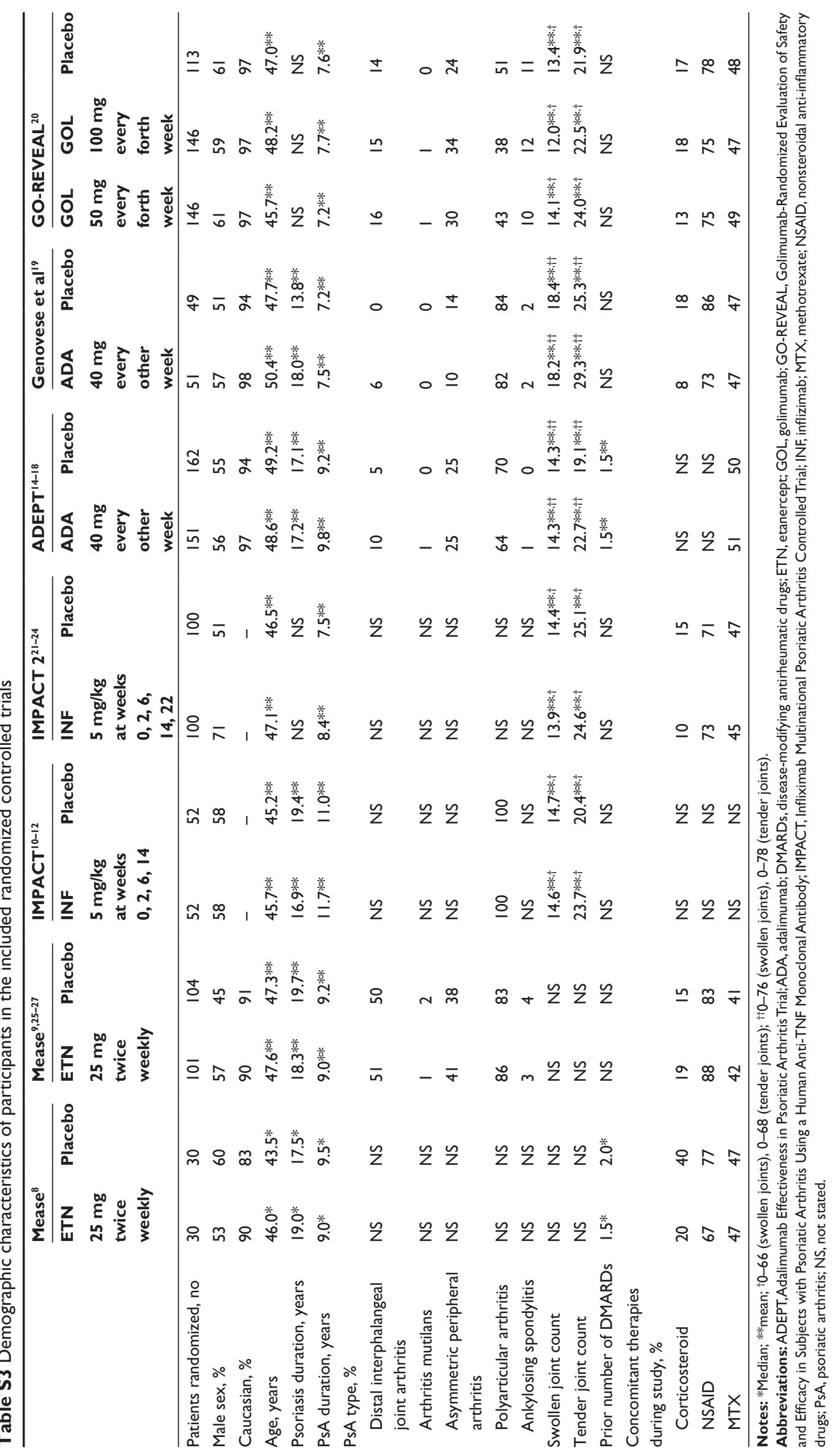


Table S4 Publications excluded after detailed evaluation

\begin{tabular}{|c|c|}
\hline Study & Reason for exclusion \\
\hline Baranauskaite et $\mathrm{al}^{28}$ & Included patients naïve to methotrexate \\
\hline Kimball et $\mathrm{al}^{29}$ & Does not exclusively include psoriatic arthritis patients; sub-analysis to randomized controlled trial \\
\hline Mease et $\mathrm{al}^{30}$ & Treatment not of interest; included inadequate responders to adalimumab, entanercept, or infliximab \\
\hline Prinz et $\mathrm{al}^{31}$ & Does not include a control arm; post hoc analysis to randomized controlled trial \\
\hline Asahina et $\mathrm{al}^{32}$ & Does not exclusively include psoriatic arthritis patients \\
\hline Atteno et $\mathrm{al}^{33}$ & Not a randomized controlled trial \\
\hline Mease et $\mathrm{al}^{34}$ & Pooled analyses of randomized controlled trials \\
\hline Sterry et $\mathrm{al}^{35}$ & Does not include a control arm \\
\hline Torii et $\mathrm{al}^{36}$ & Does not exclusively include psoriatic arthritis patients \\
\hline Van Kuijk et al $^{37}$ & Does not include outcomes of interest \\
\hline Bongiorno et $\mathrm{al}^{38}$ & Not a randomized controlled trial \\
\hline Brodszky et al ${ }^{39}$ & Not a randomized controlled trial \\
\hline Feldman et $\mathrm{al}^{40}$ & Does not exclusively include psoriatic arthritis patients \\
\hline Kristensen et $\mathrm{al}^{4 !}$ & Not a randomized controlled trial \\
\hline Ravindran et $\mathrm{al}^{42}$ & Not a randomized controlled trial \\
\hline Revicki et al $^{43}$ & Does not exclusively include psoriatic arthritis patients \\
\hline Saad et $\mathrm{al}^{44}$ & Not a randomized controlled trial \\
\hline Spadaro et $\mathrm{al}^{45}$ & Not a randomized controlled trial \\
\hline Strober et $\mathrm{al}^{46}$ & Does not include outcomes of interest \\
\hline Frankel et $\mathrm{al}^{47}$ & Not a randomized controlled trial \\
\hline Kimball et al ${ }^{48}$ & Not a randomized controlled trial \\
\hline Romero-Maté et al $^{49}$ & Not a randomized controlled trial \\
\hline Vander Cruyssen et $\mathrm{al}^{50}$ & Not a randomized controlled trial \\
\hline Fransen et $\mathrm{al}^{51}$ & Not a randomized controlled trial \\
\hline Gottlieb et $\mathrm{al}^{52}$ & Not a randomized controlled trial \\
\hline Mease et $\mathrm{al}^{25}$ & Not a randomized controlled trial \\
\hline Ritchlin $^{53}$ & Not a randomized controlled trial \\
\hline Kvien et $\mathrm{al}^{54}$ & Not a randomized controlled trial \\
\hline Rinaldi et al ${ }^{55}$ & Not a randomized controlled trial \\
\hline
\end{tabular}

\section{Publish your work in this journal}

Biologics: Targets \& Therapy is an international, peer-reviewed journal focusing on the patho-physiological rationale for and clinical application of Biologic agents in the management of autoimmune diseases, cancers or other pathologies where a molecular target can be identified. This journal is indexed on PubMed Central, CAS, EMBase, Scopus
Dovepress

and the Elsevier Bibliographic databases. The manuscript management system is completely online and includes a very quick and fair peerreview system, which is all easy to use. Visit http://www.dovepress. $\mathrm{com} /$ testimonials.php to read real quotes from published authors. 